Diabetes Mellitus. Arq. Bras. Cardiol. (2019) doi:10.5935/abc.20190134.

4. American Diabetes Association. Classification and Diagnosis of Diabetes ADA 2019. Diabetes Care42, S13-S28 (2019).

5. Nguyễn T. H. \& Phạm T. T. Khảo sát tỷ lệ rối loan chức năng tâm trương thất trái ở bệnh ninhân đái tháo đướng típ 2. Vietnam J. Diabetes Endocrinol. 43-48 (2021) doi:10.47122/ vjde.2020.44.6.

6. Uzun, G., Kirci, D., Korkmaz, L., z, A. A. \& Sayin, M. What is Good for Hypertensive Patients: Presence or Absence of Presystolic Wave. (2020) doi:10.22541/au.160157505.56187587.

7. Akyüz, A. R. et al. The relationship between presystolic wave and subclinical left ventricular dysfunction in asymptomatic hypertensive patients. Blood Press. Monit. 21, 277-281 (2016).

\title{
ĐÁNH GIÁ KẾT QUẢ PHỤC HỒI CHỨC NĂNG KHỚP GỐI SAU PHẪU THUÂ̂T NộI SOI GÕ̃ DÍNH
}

\section{TÓM TẮT}

Cứng khớp gối là một biến chứng phức tạp tiềm ẩn sau mỗi phẫu thuât hoặc chấn thương khớp gối. Có nhiều phương pháp điêu trị biến chứng này trong đó phẫu thuâat nôi soi gỡ dính đang ngày càng được ưa chuộng. Nhiều nghiên cứu trên thể giới và Việt $\mathrm{Nam}$ đều chỉ ra rằng bệnh nhân cần môt chương trình phục hồi chức năng toàn diện sau phầu thuật nội soi gõ dính khớp gối. Vì vậy chúng tôi tiến hành nghiên cứu nhằm mục tiêu: (1) Đánh giá kêt quả phục hồi chức năng vận động khớp gối sau phẫu thuật nội soi gõ dính. (2) Tìm hiểu một số yếu tố ảnh hưởng tới khả năng phục hồi chức nẳng vận động khớp gối sau phẫu thuật nội soi gõ̃ dính khớp gối. Đối tượng: 25 bệnh nhân đđược chẩn đoán cứng khớp gối sau chấn thương đã phẩu thuật nội soi gõ dính tại Bệnh viện Hữu nghị Việt Đức từ tháng 9/2020 đến tháng 7/2021. Phương pháp: tiến cứu, đánh giá trước và sau can thiệp, không có nhóm chứng. Kết quả: Tai nạn giao thông là nguyên nhân hàng đầu gây chấn thương ban đâu (76\%). Gãy xương khác ngoài xương đùi và đứt dây chằng là 2 tổn thương thường găp nhất, $52 \%$ bệnh nhân trong 2 nhóm trên có tốn thương phối hợp. Nhóm BN cứng gối sau phẫu thuật (23 BN) nhiêuu hơn nhóm điều trị bảo tồn (2 BN), tổn thương nội khớp (gãy xương nội khớp $40 \%$, tổn thương phần mềm $60 \%$ ) nhiêu hởn tổn thương ngoại khớp (16\%). Tầm vận động trung bình sau tập phục hồi chức năng 8 tuần $(118,92 \pm 14,06$ độ) tăng 56 độ so với trước mổ $(62,2 \pm 26,38$ độ). Tî lệ bệnh nhân đạt kết quả phuc hồi chức năng rất tốt tăng rõ rệt từ $8 \%$ (trước phẩu thuật) lên $92 \%$ và không có bệnh nhân loại trung bình và kém sau 8 tuần điêu trị. Nhóm tổn thương ngoai khớp có điểm HSS trung bình sau điều trị cao nhẩt $(95,5 \pm 3,11)$. Nhóm gãy xương khác có điểm HSS trung bình sau điêu trị cao nhất $(93,62 \pm 4,72) .52 \%$ bệnh nhân được phẫu thuật $g$ õ dính sau chấn thương 3-6 tháng và không có sự khác biệt có ý nghĩa thống

*Trường Đại học Y Hà Nôi

Chịu trách nhiệm chính: Lương Thu Hằng

Email: luongthuhanghb1210@gmail.com

Ngày nhận bài: 2.8.2021

Ngày phản biên khoa học: 1.10.2021

Ngày duyệt bài: 7.10.2021

\section{Lương Thu Hằng*, Phạm Văn Minh*}

kê trong kết quả điều trị giữa các nhóm thời gian phẫu thuật gỡ dính. Kết luận: Phẫu thuật nội soi gỡ dính khớp gối kết hợp với một chương trình phục hồi chức năng toàn diện đem lại hiệu quả lớn trong gia tăng tầm vận động và cải thiện chức năng khớp gối. Một số yếu tổ có ảnhh hưởng đển kết quả phục hồi chức năng khớp gối là chấn thương ban đâu gây tổn thương nội khớp hay ngoại khớp, chấn thương gây xơ dính nộ̣i khớp hay ngoại khớp, điêuu trị chấn thương bằng phẫu thuật hay bảo tồn, thời gian phẫu thuật nội soi là yếu tố cần nghiên cứu thêm.

Từ khóa: Cứng khớp gối sau chấn thương, sau phẫu thuật nội soi gõ dính

\section{SUMMARY}

\section{EVALUATE THE RESULTS OF}

\section{REHABILITATION OF KNEE JOINT AFTER}

\section{ARTHROSCOPIC ARTHROFIBROSIS}

Knee stiffness is a potentially complex complication after any surgery or injury to the knee joint. There are many treatment methods for this complication, of which arthroscopic arthrofibrosis is becoming increasingly popular. Many studies in the world and in Vietnam have shown that patients need a comprehensive rehabilitation program after arthroscopic arthrofibrosis. Therefore, we conducted a study with the following objectives: (1) Evaluate the results of rehabilitation of knee joint mobility after arthroscopic arthrofibrosis. (2) Learn some factors affecting the ability to restore knee mobility after arthroscopic arthrofibrosis knee. Subjects: 25 patients diagnosed with post-traumatic knee stiffness underwent arthroscopic arthrofibrosis at Viet Duc University Hospital from 9/2020 to 7/2021. Methods: prospective, evaluated before and after the intervention, without a control group. Results: Traffic accidents are the leading cause of primary injury $(76 \%)$. Fractures other than the femur and ligament tears are the two most common injuries, $52 \%$ of patients in the two groups above have combined lesions. The group of patients with knee stiffness after surgery (23 patients) more than the conservative treatment group (2 patients), intra-articular damage (intra-articular fracture $40 \%$, soft tissue damage 60\%) more than extra-articular damage (16\%). The average range of motion after 8 weeks of rehabilitation 
(118.92 \pm 14.06 degrees) increased by 56 degrees compared to preoperative $(62.2 \pm 26.38$ degrees). The proportion of patients with very good rehabilitation results increased significantly from $8 \%$ (preoperative) to $92 \%$ and there were no moderate and poor patients after 8 weeks of treatment. The group of extra-articular lesions had the highest mean HSS score after treatment $(95.5 \pm 3.11)$. The other fracture group had the highest mean HSS score after treatment (93.62 \pm 4.72$) .52 \%$ of patients had arthroscopic arthrofibrosis after 3-6 months of trauma, this is the group with the best treatment results with the highest mean HSS score (93.15 \pm 5.19$)$. Conclusion: Arthroscopic arthrofibrosis combined with a comprehensive rehabilitation program is highly effective in increasing range of motion and improving knee function. Some factors that affect the outcome of knee rehabilitation are the initial injury causing intraarticular or extra-articular damage, the injury causing intra-articular or extra-articular fibrosis, the treatment of the injury by surgery or conservative treatment. survival, arthroscopic arthrofibrosistime is a factor that needs further study.

Keywords: post- traumatic knee stiffness, after arthroscopic arthrofibrosis.

\section{I. ĐĂT VẤN ĐỀ}

Khớp gối là một trong những khớp đóng vai trò quan trọng trong quá trình vận động của con người. Cứng khớp gối là một biến chứng phức tạp tiềm ẩn sau mỗi phẫu thuật hoặc chấn thương khớp gối. Theo ghi nhận tại các nước phát triển tî lệ gặp biên chứng này là $11 \%$ và có thể cao hơn ở các nước đang phát triển ${ }^{3}$. Bệnh thường gặp sau chấn thương như gãy xương, bất động bột kéo dài, sau phẫu thuật ${ }^{5}$. Bệnh nhân cứng khớp gối thường gặp tình trạng đau và hạn chế tầm vận động khớp cho nên ảnh hưởng lớn đến dáng đi và các hoạt động chức năng của khớp gối. Hiện nay, có nhiều phương pháp đièu trị cứng khớp gối sau chấn thương trong đó phẫu thuật nội soi gõ dính ngày càng được ưa chuộng bởi tính an toàn, ít xâm lấn, tỉ lệ biến chứng thấp và cho phép tập phục hồi chức năng sớm ngay sau mổ. Nhiều nghiên cứu trên thế giới và Việt $\mathrm{Nam}$ đều chỉ ra rằng các bệnh nhân sau phẫu thuật nội soi điều trị cứng khớp gối cần tham gia một chương trình phục hồi chức năng toàn diệ̂n ${ }^{1,5}$. Tuy nhiên, ở Việt Nam chưa có nhiều nghiên cứu về vẫn đề này. Vì vậy chúng tôi thực hiện đề tài: "Đánh giá kết quả phục hồi chức năng khớp gối sau phẫu thuạat nội soi gõ dính"với hai mục tiêu (1) Đánh giá kết quả phục hồi chức năng vận động khớp gối sau phẫu thuật nội soi gõ dính. (2) Tìm hiểu một số yễu tố ảnh hưởng tới khả năng phục hồi chức năng vận động khớp gối sau phẫu thuật nội soi gõ̃ dính khớp gối.
II. ĐỐI TƯỢNG VÀ PHƯƠNG PHÁP NGHIÊN CỨU

Đối tượng và cỡ mẫu. Bênh nhân có tiền sử chấn thương/ bệnh lý khớp gối đã điều trị bằng phẫu thuật nội soi/ mổ mở/ bất động. Sau đó bị cứng khớp gối và được tiến hành phấu thuật nội soi gõ dính tại Bệnh viện Hữu nghị Việt Đức. Chọn mẫu thuận tiện, nghiên cứu trên 25 bệnh nhân.

\section{Phương pháp nghiên cứu}

- Tiến cứu, đánh giá trước và sau can thiệp, không có nhóm chứng.

- Tất cả các bệnh nhân cứng khớp gối sau chấn thương được phẫu thuật nội soi gõ dính khớp gối tại Bệnh viện Hữu nghị Việt Đức từ 9/2020 đến 7/2021 thỏa mãn các tiểu chí lựa chọn, đồng ý tham gia nghiên cứu được đưa vào nhóm nghiên cứu.

- Đánh giá BN theo Thang điểm khớp gối của bệnh viện phẫu thuật đặc biệt- The Hospital for Special Surgery Knee Score (viết tắt là HSS) tại 2 thời điểm: trước phẫu thuật, sau phẫu thuật 8 tuẩn.

- Các bài tập dựa theo Hướng dẫn quy trình kỹ thuật chuyển ngành Phục hồi chức năng do Bộ y tế ban hành năm 2014 kết hợp với Quy trình phục hồi chức năng sau phẫu thuật nội soi khớp gối của Đại học Chấn thương chỉnh hình, Đại học Y khoa Brown Alpert, Rhode Island, Mỹ.

BN được điều trị PHCN nội trú/ ngoại trú hằng ngày tại bệnh viện bắt đầu từ ngày thứ 1 sau mố, liên tục trong 2 tháng, $>1 \mathrm{~h} /$ buổi/ngày. Chương trình tập được chia thành 4 giai đoạn. Giai đoạn 1 (1- 7 ngày sau mổ) nhằm kiểm soát đau và sưng nề, đạt TVĐ 0- 90 độ, sử dụng nạng và nẹp duối gổi. Sử dụng bài tập gồng cơ tĩnh, vận động khớp háng, khớp cổ chân, chườm lạnh, điện kích thích cơ tứ đầu đùi. Giai đoạn 2 (1- 3 tuần sau mổ) mục tiêu đạt TVĐ và dáng đi bình thường. Tập vận động chủ động có trợ giúp, chủ động khớp gối, tập vận động có kháng trở tăng dần khớp háng, cổ chân. Giai đoạn 3 (3- 6 tuần sau mổ) mục tiêu đi bộ được $3 \mathrm{~km}$ với vận tốc $6 \mathrm{~km} / \mathrm{h}$, đi cầu thang không đau hay khó chịu. Tập vận động có kháng trở tăng dần khớp gối, tập chạy, tập thăng bằng. Giai đoạn 4 (610 tuần) nhằm trở lại sinh hoạt hàng ngày, tập chạy, rèn luyện sự nhanh nhẹn.

- Số liệu được nhập và xử lý theo chương trình SPSS 15.0. Dùng McNermar's test, Ttest ghép cặp, ANOVA test tính giá trị $\mathrm{p}$ để so sánh sự khác biệt có ý nghĩa thống kê.

\section{KẾT QUẢ NGHIÊN CỨU}

\section{1. Đặc điểm đối tượng nghiên cứu}

- Nguyên nhân chấn thương: tai nạn giao thông chiếm $76 \%$, tai nạn sinh hoạt chiếm $12 \%$. 
Các nguyên nhân khác là tai nạn thể thao, tai nạn lao động, thoái hóa khớp đều chiếm tỉ lệ 4\%.

- Các biện pháp điều trị sau chấn thương: 2 BN bảo tồn (8\%), 12 BN PT nội soi (48\%), 11 BN mổ mở (44\%)

\section{2. Đánh giá tâm vân động trung bình trước và sau đîêu trị}

Bảng 1. So sánh TVĐ̣ trung binh trước và sau điều trị

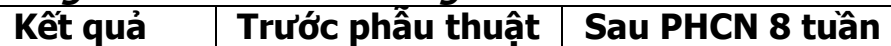

\begin{tabular}{l|l|l} 
TVĐ trung bình & $62,2 \pm 26,38$ & $118,92 \pm 13,77$
\end{tabular}

\begin{tabular}{|c|c|c|}
\hline Trong phấu thuật & p1 & p2 \\
\hline $117,6 \pm 16,08$ & 0,000 & 0,8112 \\
\hline
\end{tabular}

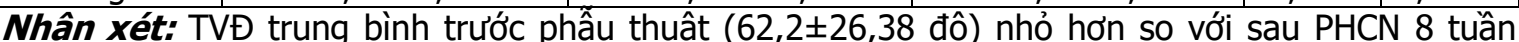
$(118,92 \pm 13,77)$ với sư khác biêtt có ý nghĩa thống kê $\mathrm{p} 1=0,0000<0.01$. TVĐ trung bình sau PHCN 8 tuần và trong phẫu thuật xấp xỉ bằng với sự khác biệt không có ý nghĩa thống kê p2=0,8112> 0,01 (sử dụng Ttest ghép cặp)

3.3. Đánh giá kết quả PHCN trước và sau điêu trị

Bảng 2: Đánh giá kết quả PHCN trước và sau điều trị

\begin{tabular}{|c|c|c|}
\hline Xếp loại Thời điếm & Trước phẫu thuật & Sau PHCN 8 tuân \\
\hline Rất tốt & $8 \%$ & $92 \%$ \\
\hline Tốt & $40 \%$ & $8 \%$ \\
\hline Trung bình & $24 \%$ & $0 \%$ \\
\hline Kém & $28 \%$ & $0 \%$ \\
\hline Tống số & $100 \%$ & $100 \%$ \\
\hline
\end{tabular}

Nhân xét: Trước phẫu thuật có $8 \%$ bệnh nhân đạt kết quả rất tốt, $40 \%$ tốt, $24 \%$ trung bình, $28 \%$ kém. Sau PHCN 8 tuần, chỉ có 2 nhóm là rất tốt $92 \%$ và tốt $8 \%$.

3.4. So sánh kết quả điều trị giữa các nhóm chấn thương

Bảng 3. So sánh kêt quả PHCN giữa các nhóm chân thương

\begin{tabular}{|c|c|c|c|}
\hline Tổn thương & \multicolumn{2}{|c|}{ Tổn thương nội khớp } & \multirow{2}{*}{$\begin{array}{l}\text { Tổn thương ngoại } \\
\text { khớp }\end{array}$} \\
\hline Kết quả & Gãy xương nôi khớp & Tổn thương phân mềm & \\
\hline Số lượng & $10(40 \%)$ & $15(60 \%)$ & $4(16 \%)$ \\
\hline Điểm HSS trung bình & $92,6 \pm 4,43$ & $92,93 \pm 5,15$ & $95,5 \pm 3,11$ \\
\hline
\end{tabular}

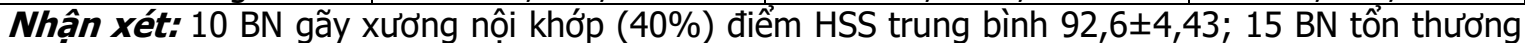

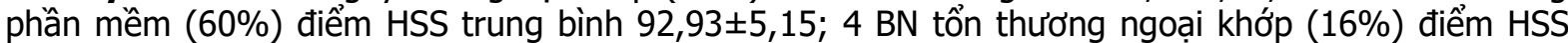
trung bình 95,5 $\pm 3,11$.

3.5. So sánh kết quả điêu trị giữa các nhóm cấu trúc tổn thương

Bảng 4. So sánh kêt quả điểu trị giữa các nhóm câu trúc tổn thương

\begin{tabular}{|c|c|c|c|c|c|}
\hline Kết quả & $\begin{array}{c}\text { Gãy xương } \\
\text { đùi }\end{array}$ & $\begin{array}{c}\text { Gãy xương } \\
\text { khác }\end{array}$ & $\begin{array}{c}\text { Đứt dây } \\
\text { chằng }\end{array}$ & $\begin{array}{c}\text { Rách sụn } \\
\text { chêm }\end{array}$ & Thoái hóa \\
\hline Số lượng & $4(16 \%)$ & $13(52 \%)$ & $13(52 \%)$ & $4(16 \%)$ & $1(4 \%)$ \\
\hline Điếm HSS trung bình & $93,5 \pm 2,65$ & $93,62 \pm 4,72$ & $92,77 \pm 5,15$ & $90 \pm 3,37$ & 84 \\
\hline
\end{tabular}

Nhân xét: Sau 8 tuần PHCN điểm HSS trung bình của 4 BN gãy xương đùi $(16 \%)$ là 93,5 $\pm 2,65$;

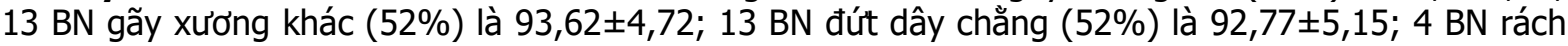
sụn chêm (16\%) là 90ะ3,37; 1 BN thoái hóa khớp gối (4\%) là 84.

3.6. So sánh kết quả điều trị giữa các nhóm thời gian từ lúc chấn thương đến khi phẫu thuật gõ̃ dính

Bảng 5. So sánh kêt quả đîều trị giữa các nhóm thởi gian từ lúc chấn thương đến khi phẫu thuật gõ dính

\begin{tabular}{|c|c|c|c|c|}
\hline Kết quả & $<3$ tháng & Từ 3-6 tháng & $\mathbf{> 6}$ tháng & p \\
\hline Số lượng & $3(12 \%)$ & $13(52 \%)$ & $9(36 \%)$ & 0,7147 \\
\hline Điểm HSS trung bình & $90,67 \pm 1,15$ & $93,15 \pm 5,19$ & $92,78 \pm 4,49$ & \\
\hline
\end{tabular}

Nhận xét: 3 BN phấu thuật gõ dính trong vòng 3 tháng sau chấn thương có điểm HSS trung bình là $90,67 \pm 1,15$ điểm; 13 bệnh nhân nhóm 3- 6 tháng đạt 93,15 55,19 điểm; 9 bệnh nhân nhóm trên 6 tháng đạt $92,78 \pm 4,49$ điểm. Không có sự khác biệt có ý nghĩa thống kê trong kết quả điều trị giữa các nhóm thời gian phẫu thuật gõ dính với $p=0,7147>0,01$ (ANOVA test). 


\section{BÀN LUÂN}

4.1. Đặc điểm đối tượng nghiên cứu. Nguyên nhẩn hàng đầu gây chấn thương ban đầu cho các bệnh nhân cứng khớp gối sau chấn thương là tai nạn giao thông (chiếm 76\%), lý giải bởi tại Việt Nam tai nạn giao thông là nguyên nhân hàng đầu gây chấn thương chi dưới.

Gãy xương khác ngoài xương đùi (13 bệnh nhân) và đứt dây chằng (13 bệnh nhân) là 2 tổn thương thường gặp nhất, 52\% bệnh nhân trong 2 nhóm trên có tổn thương phối hợp. Điêu này cho thấy cứng khớp gối sau chấn thương thường gặp sau các tổn thương nặng và phối hợp.

Sau chấn thương, số BN phẩu thuật (12 BN phẫu thuật nội soi, $11 \mathrm{BN}$ mổ mở) nhiêu hơn hẳn số $B N$ điều trị bảo tồn (2 BN), như vậy cứng khớp gối thường gặp ở các BN đã phẫu thuật khớp.

Thời gian TB từ khi chấn thương đến khi PT nội soi gõ̃ dính: nhóm PT nội soi TB 6 tháng (319 tháng), nhóm mổ mở TB 11 tháng (2- 31 tháng), nhóm bảo tồn TB 4 tháng.

Các tổn thương nội khớp (gãy xương nội khớp 40\%, tổn thương phần mềm 60\%) dề gây cứng khớp hơn các tổn thương ngoai khớp (16\%). Điều trị tổn thương nội khớp thường bằng phẫu thuật, trong khi chấn thương và PT can thiệp vào khớp là nguyên nhân trực tiếp gây xơ dính nội khớp. Chấn thương ngoại khớp gây cứng khớp chủ yễu do bất động lâu ngày.

$12 \%$ BN phâu thuật gỡ dính trong 3 tháng sau chân thương (2 tháng 12 ngày- 2 tháng 26 ngày), $52 \%$ phẫu thuật gõ dính sau chấn thương 3-6 tháng (3 tháng- 6 tháng 15 ngày). 36\% phẫu thuật sau chấn thương trên 6 tháng $(7$ tháng- 2 năm). Hơn một nửa (52\%) BN phẩu thuật gõ dính sau chấn thương 3- 6 tháng, phù hợp với nghiên cứu của Abhishek Vaish và CS nằm 2020, N. Pujol và CS năm 2014 đều cho rằng $\mathrm{PT}$ gõ dính đạt hiệu quả nhất khi thực hiện sau chấn thương 3-6 tháng ${ }^{7}$.

4.2. Đánh giá kết quả. TVĐ trung bình sau PHCN 8 tuần $(118,92 \pm 14,06$ độ) tăng 56 độ so với trước mổ $(62,2 \pm 26,38$ độ) và xấp xỉ bằng TVĐ trong mổ $117,6 \pm 16,08$. Tương đồng với số liệu trong nghiên cứu của Liu $\mathrm{SH}$ và CS năm $2016(117 \pm 13,4)^{4}$. Chương trình tập PHCN trong 8 tuần giúp cải thiện rõ rệt TVĐ khớp gối và đạt mục tiêu như trong mổ.

Sau điều trị PT và PHCN, tỉ lệ BN đạt kết quả rất tốt tăng rõ rệt từ $8 \%$ (trước phẫu thuật) lên $92 \%$, không có BN loại trung bình và kém. Chỉ 1 BN thoái hóa khớp đã phẫu thuâat thay khớp gối có điểm HSS là 84 thuộc nhóm tốt, 24 BN còn lại đều đạt kết quả rất tốt. Từ đó cho thấy chương trình điều trị đem lại hiệu quả cao trong phục hồi vận động khớp gối.

4.3. Các yếu tố liên quan. Nhóm tổn thương ngoại khớp có điểm HSS trung bình sau điều trị cao nhất $(95,5 \pm 3,11)$. Nhóm này không có chấn thương hay can thiệp trực tiếp vào khớp mà cơ chế cứng khớp là do bất động lâu ngày nên tình trạng xơ dính thường không nặng nề, hiệu quả hồi phục cao hơn nhóm tổn thương nội khớp $p^{6}$.

Các BN nhóm gãy xương khác có điểm HSS trung bình sau điều trị cao nhất $(93,62 \pm 4,72)$. Do chấn thương không liên quan đến xương đùi nên không gặp tình trạng xơ dính gân cơ tứ đâu đùi và mô mềm vùng đùi, hiệu quả phục hồi sẽ tốt hơn ${ }^{6}$.

Các BN ở cả 3 nhóm thời điểm phẫu thuật gõ dính đều có điểm trung bình HSS rất cao tuy nhiên sự khác biệt không có ý nghĩa thống kê $(p=0,7147)$, khác với kết quả nghiên cứu của Lena Alm và CS năm 2019 cho rằng nhóm phẫu thuật gõ dính muộn có kết quả kém hơn nhóm gõ dính sớm. Nguyên nhân của sự khác biệt này do cõ̃ mẫu chưa đủ lớn ${ }^{8}$.

\section{KẾT LUẬN}

PT nội soi gõ dính khớp gối kết hợp với chương trình PHCN toàn diện đem lại hiệu quả lớn trong gia tăng $T V \bigoplus$ và cải thiện chức năng khớp gối. Chương trình $\mathrm{PHCN}$ bao gồm các bài tập gia tăng TVĐ, cải thiện sức mạnh cơ, kiểm soát đau và sưng nề trong giai đoạn đầu kết hợp với bài tập thăng bằng, cải thiện sự linh hoạt, các bài tập chuyên biệt giúp BN trở lại hoạt động thể thao trong giai đoạn sau.

Một số yếu tố có ảnh hưởng đến kết quả phục hồi chức năng khớp gối là chấn thương ban đầu là tổn thương nội khớp hay ngoại khớp, chấn thương chỉ gây xơ dính nội khớp (đứt dây chằng, rách sụn chêm, gãy xương khác, thoái hóa) hay còn gây xơ dính ngoại khớp ở mô mềm vùng đùi (gãy xương đùi), sau chấn thương $B N$ được điều trị phẫu thuật hay bảo tồn. Trong nghiên cứu này thời điểm phẫu thuật nội soi gõ dính không ảnh hưởng đến kết quả PHCN khớp gối, tuy nhiên cần nghiên cứu với cỡ mẫu lớn hơn.

\section{TÀI LIÊU THAM KHẢO}

1. Nhân, Đỗ Trọng. Đánh giá kết quả phẫu thuật nộ soi điều trị hạn chế vấn động khớp gối sau chấn thương. Đại học Y Hà Nội, 2019.

2. Bonutti PM, McGrath ḾS, Ulrich SD, McKenzie SA, Seyler TM, Mont MA. Static progressive stretch for the treatment of knee stiffness. The Knee. 2008;15(4):272-276.

3. Liu K, Liu S, Cui Z, Han X, Tang T, Wang A. A less invasive procedure for posttraumatic knee stiffness. Arch Orthop Trauma Surg. 
2011;131(6):797-802

4. Liu Sh, Liu km, Wang aq, Gui zg, Han xz, Wang f. Management strategies for posttraumatic knee stiffness. Biomedical. 2016.

5. Parisien JS. The role of arthroscopy in the treatment of postoperative fibroarthrosis of the knee joint. Clin Orthop. 1988;(229):185-192.

6. Pujol $N$, Boisrenoult $P$, Beaufils $P$. Posttraumatic knee stiffness: Surgical techniques.
Orthop Traumatol Surg Res. 2015;101(1 Supplement):S179-S186.

7. Vaish A, Vaishya R, Bhasin VB. Etiopathology and Management of Stiff Knees: A Current Concept Review. Indian J Orthop. 2021;55(2):276-284.

8. Alm L, Klepsch L, Akoto R, Frosch K-H. Arthrofibrosis of the knee: clinical result after early vs. late arthroscopic arthrolysis of 100 patients. Orthop J Sports Med. 2020;8

\section{KÊTT QUẢ HÓA XA TRỊ ĐỒNG THỜI PHÁC ĐỒ EP VÀ KĨ THUẬT XẠ ĐIỀU BIẾN LIỀU TRONG UNG THƯ PHỔI KHÔNG TẾ BÀO NHỎ GIȦI ĐOẠN III}

\section{TÓM TẮT}

Mục tiêu: Đánh giá kết quả điều trị của phác đồ EP kết hớp với xa trị điều biến liều trong ung thư phổi không tế bào nhỏ giai đoạn III và mô tả một số tác dụng không mong muốn của điều trị trên. Đổi tượng nghiên cứu: Gồm 37 bệnh nhân UTPKTBN giai đoạn III được điêu tri hoá xa tri đồng thời bằng kĩ thuât xa điêu biến liêu và phác đồ hoá chất etoposide-cisplatin tại Bệnh viện K từ 01/2019 đến 06/2021. Phương pháp nghiển cứu: mô tả cắt ngang. Kết quả: Đặc điểm nhóm nghiên cứu: Tuổi trung bình 57 , tỉ lệ nam chiến $86,5 \%$, bệnh nhân được lựa chọn có thể trạng tốt với $22(59.5 \%)$ trong 37 bệnh nhẩn ECOG 0. Giai đoạn bệnh chủ yếu là giai đoạn IIIB chiếm $62,2 \%$, mô bệnh học chủ yếu là carcinoma tuyến $64.9 \%$. Kết quả điều tri: Đánh giá đáp ứng theo RECIST 1.1 cho thây tî lệ đáp ứng toàn bộ, một phần tương ứng là $2,7 \%$ và $83,8 \%$, tỉ lệ kiểm soát bệnh là $97,3 \%$. Thời gian trung vị sống thêm không tiến triển là $14 \pm 3,7$ tháng. Sống thêm không tiến triển vào thời điểm 12 tháng là $54,7 \%$ là Độc tính: Có 24,3\% bệnh nhân viêm phổi, $44,2 \%$ bệnh nhân viêm thực quản chỉ ở độ I, II. Độc tính trên hệ tạo huyết chủ yếu độ I, II, chỉ có $2,7 \%$ bênh nhân xuất hiện độ III. Độc tính trên gan, thân, nổn, mệt mỏi, sụt cân đều ở mức độ 1-2. Kết luận: Phác đồ không những cho kết quả khả quan về đáp ứng và sống thêm không tiến triển, mà còn giảmđáng kể các độc tính liên quan đến xa trị

Tư khóa: Ung thư phổi khổng tế bào nhỏ, hóa xạ trị đồng thời, EP, tỉ lệ đáp ứng, độc tính.

\section{SUMMARY \\ RESULTS OF CONCURRENT CHEMORADIOTHERAPY WITH ETOPOSIDE - CISPLATIN REGIMEN AND INTENSITY}

\footnotetext{
${ }^{1}$ Trường Đại học Y Hà Nội

²Bệnh viện $K$ trung ương

Chịu trách nhiệm chính: Nguyễn Quang Anh

Email: quanganhyd@gmail.com

Ngày nhận bài: 3.8.2021

Ngày phản biên khoa họ: 1.10 .2021

Ngày duyệt bài: 8.10.2021
}

\section{Nguyễn Quang Anh' ${ }^{1}$, Đỗ Hùng Kiên², Nguyễn Văn Tài ${ }^{2}$, Lê Thị Yến ${ }^{2}$}

MODULATE RADIATION IN STAGE III NON - SMALL CELL LUNG CANCER

Objectives: To evaluate the treatment results of EP regimen combined with dose-modulated radiotherapy in stage III non-small cell lung cancer and describe some undesirable effects of the treatment regimen. Patients and methods: 37 patients with stage III NSCLC who received chemotherapy and radiotherapy concurrently with intensity modulated radiation therapy and etoposidecisplatin chemotherapy regimen at K Hospital from January 2019 to June 2021. Results: Study group characteristics: Mean age 57, men account for $86,5 \%$, selected patients were in good performance status with $22(59,5 \%)$ in 37 ECOG 0 patients. Stage host disease mainly stage IIIB accounts for $62.2 \%$, histopathology is mainly adenocarcinoma $64.9 \%$. Treatment results: Evaluation of response according to RECIST 1.1 showed that the rate of complete and partial response was $2,7 \%$ and $83,8 \%$, respectively. Progression-free survival was $14 \pm 3,7$ months. Progression-free survival at 12 months $54,7 \%$ was Toxicity: There were $24,3 \%$ pneumonia patients, $44,2 \%$ esophagitis patients only grade I, II. Toxicity on hematopoietic system mainly grade I, II., only $2.7 \%$ of patients appeared grade III. Toxicity on liver, kidney, vomiting, fatigue, weight loss are at 1-2 levels. Conclusion: The regimen not only gave good results in terms of response rates and progression-free survival, but also significantly reduced radiationrelated toxicity

Keywords: Lung cancer, concurrent chemoradiotherapy, EP, response rate, toxicity..

\section{I. Đă̆T VẤN ĐỀ}

Hóa xạ trị đồng thời là phương pháp điều trị chuẩn ở bệnh nhân ung thư phổi không tế bào nhỏ (UTPKTBN) giai đoạn III không có chỉ định phẫu thuật. Giai đoạn này gặp khoảng 30\% tại thời điểm chẩn đoán ban đâu và tỷ lệ sống thêm 5 năm dao động từ $5 \%$ đến $17 \%$, kết quả này phụ thuộc vào phương pháp điêu trịi ${ }^{1}$. Việc phối hợp hoá xạ trị có hai mục đích, một là hoá chất 